\title{
SAMBANDHA DALAM BEBERAPA PRASASTI BALI
}

\author{
Oleh : I GUSTI PUTU EKAWANA
}

\section{PENDAhuluan.}

Di kalangan para terpelajar tentu sudah pernah mendengar perkataan prasasti. Lebih-lebih lagi di kalangan pencinta sejarah, sejarah kuna khususnya. Yang dimaksud dengan prasasti ialah sumber-sumber sejarah dari masa lampau yang ditulis di atas batu atau logam. Sebagian terbesar dari prasasti-prasasti tersebut dikeluarkan oleh raja-raja yang memerintah di berbagai kepulauan Indonesia sejak abad ke 5 (Boechari, 1977: 2).

Dari prasasti dapat diketahui bermacam-macam hal seperti nama raja, nama-nama pejabat kerajaan, data pertanian, peternakan, bangunan-bangunan suci dan sebagainya. Beberapa sarjana telah menulis topik pembicaraan dengan memanfaatkan prasasti sebagai sumber penulisan. Misalnya Machi Suhadi menulis sistim perpajakan di dalam prasasti Jawa Kuna (Machi Suhadi, 1978), Riboet Darmosoetopo menulis tentang pergantian tahta kerajaan Indonesia Kuna (abad 4-11 M) (Riboet Darmosoetopo, 1980: 52-57), Ida Bagus Purwita menulis tentang subak dalam lintasan sejarah Bali (Purwita, 1981: 29-33) dan banyak karangan lainnya lagi yang dimuat dalam majalah-majalah maupun makalah yang dibawakan dalam seminar.

Sebagaimana halnya dengan Negara Republik Indonesia di dalam mengeluarkan suatu peraturan maupun undang-undang baik oleh pemerintah pusat maupun daerah ada tujuan dan latar belakangnya. Demikian pula keluarnya surat keputusan tentu ada pula latar belakangnya yang menyebabkan diambilnya keputusan itu. Begitu pula dalam jaman kerajaan Indonesia Kuna suatu desa atau seseorang diberi anugerah prasasti ada latar belakangnya. Suatu desa atau seseorang mendapat anugerah prasasti masing-masing mempunyai alasan tersendiri. Jelasnya masing-masing prasasti mempunyai perbedaan isi.

Pada kesempatan ini akan dicoba untuk menguraikan secara singkat masalah tentang sebab-sebab prasasti dianugerahkan oleh raja. Berdasarkan pembacaan pada beberapa prasasti Bali sebab-sebab atau alasan suatu desa mendapat anugerah prasasti ada secara jelas disebut latar belakangnya tetapi ada pula yang tidak disebutkan. 
Di dalam prasasti alasan atau sebab-sebab suatu prasasti dikeluarkan oleh raja dapat diketahui pada bagian yang memuat sambandha. Pada sambandha inilah kita dapat mengetahui latar belakang suatu karäman mendapat anugerah prasasti. Kalau kita perhatikan sambandha prasasti itu bermacam-macam antara lain, menyebutkan tentang masalah bwatthaji, buñcang haji berupa pajak yang dirasakan berat, ingin menjadi desa berdiri sendiri (merdeka), penduduk berkurang karena banyak yang mati dan ditawan musuh sehingga merasa berat memikul beban pajak, merasa berat mengerjakan kebun milik raja, mempersembahkan sima untuk bangunan suci dan sebagainya. Dengan bermacam-macam latar belakang itu sebagai alasan atau sebab-sebab seorang raja lalu menganugerahkan prasasti setelah melalui sidang lengkap kerajaan. Prasasti merupakan pegangan (agěmmagěm) untuk mengokohkan kedudukan satu karāman. Menurut Goris prasasti adalah merupakan undang-undang (Goris, 1948: 22). Oleh karena itu jelaslah bahwa prasasti sebagai undang-undang, merupąkan dasar hukum yang dipergunakan sebagai pegangan (agémmagđm) yang memuat hak-hak dan kewajiban bagi sebuah karāman yang harus ditaati oleh semua pihak.

Kalau kita perhatikan arti perkataan sambandha dapat berarti bermacam-macam seperti: 'ikatan, hubungan, hubungan/derajat keluarga, tumbuh, sebab, musabab, lantaran, karena, sudah waktunya untuk, seolaholah, semestinya' (Mardiwarsito, 1981: 498). Dari sejumlah arti perkataan itu kiranya tidak dapat diartikan secara kaku dengan satu perkataan saja melainkan dapat berubah-ubah menurut konteks kalimat prasasti. Di dalam menafsirkan arti perkataan sambandha tersebut kiranya yang sesuai untuk dipergunakan adalah 'sebab, musabab, lantaran'. Di samping berarti seperti di atas ini dapat pula ditafsirkan dengan 'maksud, tujuan, alasan'.

Sebagai suatu karangan yang membicarakan salah satu aspek prasasti senarusnya dapat menguraikan secara terperinci tetapi pada karangan ini saigat jauh dari pada itu. Di sini tidak akan disebutkan semua sambandha dar: prasasti Bali melainkan hanya diambil beberapa saja sebagai contoh. Demikian pula pembahasan yang dilakukan hanya sepintas saja sehingga lebih tepat dikatakan sebagai suatu pengantar ke arah penelitian lebih lanjut.

\section{DATA PRASASTI}

Seperti telah disinggung pada uraian di muka bahwa tidak akan dikemukakan semua sambandha pada prasasti Bali tetapi dipakai beberapa saja sebagai contoh. Dari sejumlah prasasti yang telah dibaca ternyata prasasti itu sambandhanya bermacam-macam. Dari sejumlah prasasti yang dipakai contoh beberapa di antaranya sambandhanya tidak jelas menyebut latar belakang masalah yang dihadapi oleh penduduk atau karaman. Sebagai gambaran dari sambandha dikemukakan sebagian kutipan prasasti yang memuat bagian yang penting dari prasasti itu. Untuk lebih melengkapi uraian di bawah ini diberikan pula terjemahan terhadap kutipan pra- 
sasti tersebut. Adapun kutipan dari bagian prasasti yang memuat sambandha seperti di bawah ini.

1. Prasasti Serai A II (Goris no. 302), bertahun Saka 915, dikeluarkan oleh raja suami-istri Gunapriya Dharmapatni dan Udayana.

IIa. 4. sambandha, hentwa mabwatthaji di buru matahi

5. lang drwya haji pangrotña māsu 9 hatmwang hatwamwang di nayakaña, kunang pwan tani pamrih tumahilang hentwa mẩsu 9..... (Goris, 1954: 81).

Terjemahannya lebih kurang sebagai berikut:

IIa. 4. 'lantaran orang-orang yang melakukan bwatthaji.' di Buru, membayar drwya haji.2 (berupa) pajak rot. ${ }^{3} 9$ māsu setiap tahun kepada nayakan. ${ }^{4}$ nya, oleh karena tidak dapat memenuhi membayar sebesar 9 masu .....'

2. Prasasti Bwahan A (Goris no. 303), bertahun \$aka 916, dikeluarkan dikeluarkan oleh raja suami-istri Gunapriya Dharmapatni dan Udayana.

I. 6. kunang sangkā ri hyun ikang karāmān i wing kang ranu bwahan sumehakna sarintěnya, ma

7. ryya salapkna mwang ikang karămān i wingkang rangu kdisan, yăthanyan sutantră i käwakanya, matangnyan panambah ikang kārāman i wingkang rạ̣u

8. bwahan i haji sajalustri, mahyang anugraha aminta prașasti ...... (Goris, 1954: 83).

Terjemahannya lebih kurang sebagai berikut:

I. $\quad 6$. . . . . oleh karena keinginan karämān. ${ }^{5}$ tepi danau Bwahan hendak memisahkan badannya

7. berhenti (bergabung) secara musyawarah (baik-baik) dengan karāmān tepi danau Kdisan, supaya bebas berdiri sendiri (merdeka) karena itu datang menyembah karämān tepi danau

8. Bwahan kehadapan raja suami-istri memohon anugerah meminta prasasti, .......

3. Prasasti Sembiran A III (Goris no. 351), bertahun Saka 938, dikeluarkan oleh Sang Ratu S ri Sangajhădewi.

VIa. 3. . . . . . makatahwang ram paraspara uraña habanwa,

4. mati, me tyaban musuh, nguniweh lwas majěngan di banwa johan, kawkas ta ya kuṛn 50 ghyäni, mula kurn 300 kunang sangka ri tani pra

5. h misinin to drabyahajiña ș̣angña paripūrṇna tkā di halyun bun̂cang haji saprakära, ya ta mangjadyang sakit kepwan di ya, ya ta haitu na ma

6. nambah di sang ratu, mangidhih anugraha titisyānambrta, ...... (Goris, 1954: 95). 
Terjemahannya lebih kurang seperti berikut:

VIa. 3. . . . . ., memberitahukan musyawarah tentang kekacauan seluruh desa,

4. (karena) mati dan ditawan musuh, lebi-lebih lagi pergi berlindung (majěngan?) di desa berjauhan (johan), akhirnya sekarang bersisa 50 keluarga, pada mulanya 300 keluarga. Oleh karena tidak mampu

5. mengisi (membayar) drabyahajiña secara lunas pada waktunya, sampai dengan segala macam buñcang haji. ${ }^{6}$ hal itu menjadikan sakit hati mereka (penduduk) itulah sebabnya

6. menyembah kehadapan baginda raja memohon tetesan ambrta (air untuk hidup) . . . . . .

4. Prasasti Batuan (Goris, no. 352) bertahun Saka 944, dikeluarkan oleh raja Sri Dharmmawangsawardhanamarakapangkajasthānottunggadewa.

Ib. 4. . ......, makasammbanda, majarakěn bhara ni buñcang hajinya makmitan kebwan pāduka haji sang siddha dewata lumah ring nger wka, ing nger paku, .... (Goris, 1954: 96).

Terjemahannya lebih kurang seperti di bawah ini:

Ib. 4. . . . . . . bermaksud (dengan alasan) menyampaikan beratnya bưncang haji-nya menjaga kebun baginda raja yang te-. lah menjadi dewa (mencapai alam dewa) yang dicandikan (lumah ?) di Er Wka, di Er Paku, . . . . .

5. Prasasti Sawan A I = Bila A I (Goris, no. 353), bertahun Saka 945 dikeluarkan oleh raja Dharmawangsawardhanamarakatapangkajasthanottunggadewa.

Ib. 2. . . . . ., sambandha majaraken paraspara ni hambanya sakarăman mula 50 kurgn kwehnya nguni ring muhun mala

3. ma, maśeśa ta ya 10 kựn, kunang sangkā ri kabyetanya ring drwya haji, mwang buňcang haji magongadmět, tka ring pinta palaku pamli, pikupikulan, ..... (Goris, 1954: 101).

Terjemahannya lebih kurang sebagai di bawah ini:

Ib. 2. . . . . ., adapun sebabnya (mereka menghadap) menyampaikan hasil musyawarah yang semula (penduduk) banyaknya 50 keluarga jumlahnya dahulu

3. (kini bersisa hanya 10 keluarga, oleh karena beratnya drwyahaji dan bun̆cang haji besar maupun kecil, termasuk pula pinta palaku pamli.? pikul-pikulan, .......

6. Prasasti Trunyan A II (Goris, no. 402), bertahun Saka 971, dikeluarkan oleh raja Anak Wungśu.

IVb. 2. ......., sambandha ni panambah nikāng karāman i turựan sapasuk thāni, rì paduka haji, anghyang amintanugraha, an paǧ̌hakna sarasani prasāsti 
3. nya mūla atěhěr tamb̄rakna, makanimitta wuk riptanya, ya ta karananyan anghyang anambah ri păduka haji, ....... Callenfels, 1926: 22).

Terjemahannya lebih kurang sebagai berikut:

IVb. 2. . . . . . sambandha ni panambah nikāng karaman i turuñan sapasuk thani, ri paduka haji, anghyang amintanugraha, an pagehákna sarasani prasāsti

3. nya müla atěhěr tambrakna, makanimitta wuk riptanya, ya ta karananyan anghyang anambah ri pãduka haji ...... (Callenfels, 1926: 22).

Terjemahannya lebih kurang sebagai berikut:

IVb. 2. . . . . , berdasarkan alasan menyembahnya karaman di turunan dengan seluruh wilayah (penduduk) kehadapan baginda raja, memohon meminta anugerah untuk mengokohkan isi maksud (inti) prasasti

3. yang dulu, selanjutnya disalin pada tembaga, oleh karena rusak riptanya (rontalnya), itulah sebabnya memohon, menyembah kehadapan baginda raja, ......

7. Prasasti Pandak Bandung (Goris, no. 436) bertahun Saka 993, dikeluarkan oleh raja Anak Wungsu.

Ib. 2. . . . . . . umarpanakĕn, ikang sima marajang mapakna punpunan sanghyang dharmma ring ngantakunjarapāda, sambandha dinwal tkap i wka wet sang atita prabhu lumah ing senämukha, mangara

3. n dyah jasa mwa dyah manali, dyah citta, ring mā su 5 i lwu ni päduka haji, tke alasnya sawahnya parlaknya, agaduh manarimakén pirak samgat ser camalagi mangaran maholka, ...... (Callenfels, 1926: 14).

Terjemahannya lebih kurang sebagai berikut:

Ib. 2. . . . . . mempersembahkan sima. Marajang diperuntukkan bagi punpunan. ${ }^{9}$ sanghyang dharmma ${ }^{10}$ di Antakunjarapāda, lantaran (berdasarkan alasan) dijual oleh keturunan raja yang lampau yang lumäḥ di Senāmukha, bernama

3. Dyah Jasa, Dyah Manali dan Dyah Citta, seharga 5 ma su ke-. hadapan debu baginda raja serta hutan dan sawahnya, kebunnya, bertindak membayarkan pirak (uang perak) samgat ser camalagi. ${ }^{11}$ bernama Maholka ..... .

8. Praasasti Pura Pamrajan Raja Purana $=$ Klungkung A (Goris, no. 439) bertahun Saka 994, dikeluarkan oleh raja Anak Wungsu.

Ib. 2. . . . . ., sambandhăhyūn gumawaya ikanang sawah kadandan i kaswakan rawas kramanya pina:

3. lakunya läga pariduh manahura sapurwwasantätinya mula ma 5 saputhayu, ...... (Callenfels, 1926: 60). 
Terjemahannya lebih kurang sebagai berikut:

Ib. 2. . . . . . . . berdasarkan alasan (sebab) ingin membuat sawah kadandan.$^{12}$ di kaswakan. ${ }^{13}$ Rawas, yaitu perihal dikenakan biaya

3. läga pariduh. ${ }^{14}$ supaya membayar kembali seperti peraturan semula yalah sebesar 5 ma setiap orang, ......

9. Prasasti Bwahan C (Goris, no. 554) bertahun Saka 1068, dikeluarkan oleh raja Jayasakti.

Ib. 4. ......., sambandha ni panambah hikanang karäman i wingkang ranu maser i lbū ni padūka śri mahārāja, majarakén susahnyan'gĕnangěnya maka ni

5. mitta pinuripurihan dening cakșu paracaksu, kinditan wineh umagěhakěn sapǔrwwāsthitinya ri lāgi, ..... (Callenfesl, 1926: 33).

Terjemahannya lebih kurang sebagai berikut:

Ib. 2. . . . . lantaran menyembahnya karāman tepi danau (Bwahan) dengan tertib kehadapan debu Paduka Sri Maharaja menyampaikan tentang pikiran yang susah

5. oleh karena dipermainkan (diperdayakan) oleh cakșu paracaksu. ${ }^{15}$ (mohon) diberi pegangan (prasasti) untuk méngokohkan sebagai semula sejak dahulu, ........

10. Prasasti Tejakula (Goris, no. 571) bertahun Saka 1077 dikeluarkan oleh raja Rāgajâya.

Ib. 2. ....., sambandhā ni pangalocitanira, umingětingět ikang karäman anung yogya kaparnaha jätaka bhațā

3. ra ri kuñjarāsana, makahetu ri tan angganira majătaka katunggnah anghuningi ri bhațāra, matangnyan inundang karamani sabhaya sapañjing thani, datang ta ya mampakampak akrigan mapulung

4. rahi umaturi lbuni paduka sri mahărăja, . . . . (Ginarsa, 1974: 14).

Terjemahannya lebih kurang sebagai di bawah ini:

Ib. 2. . . . adapun maksud dari pertemuan baginda itu, untuk mengingat-ingatkan desa manakah yang layak ditempatkan di wilayah tanah suci (jatăka). ${ }^{16}$

3. milik Bhaţāra ${ }^{17}$ di Kunjarăsana. Apabila mereka tidak setuju (ingin). ditunjuk untuk mengerjakan tanah jatăka itu supaya melaporkan kehadapan Bhațära. Dari sebab itulah karaman Sabhaya dengan seluruh penduduk (wilayah) dipanggil (oleh raja). Maka datanglah mereka serentak berduyun-duyun tidak ada yang ketinggalàn

4. bertatap muka menyembah debu Paduka Sri Maharaja, .... 
11. Prasasti Campaga A (Goris, no. 631) bertahun Saka 1103 dikeluarkan oleh raja Jayapangus.

Ib. 4. . . . . sambandha mangrěngö päduka sri mahärāja, ri katidopaya ni

5. kang karāman, epu kapgan, tan wringdãya alah holahālěh mawicara lawan sang admak akmitan a pigājih, angkěn cetramāsa, ya ta du

6. madyakěn trasantasah nikang kārāman jmur, tan pahāmngan, ..... (Callenfels, 1926: 46).

Terjemahannya lebih kurang sebagai berikut:

4. . . . berdasarkan alasan (sebab) Paduka Sri Maharaja; mendengar tentang keragu-raguan (kebingungan) tidak tahu daya upaya

5. karaman (Campaga) sesak kebingungan, tidak tahu daya upaya, lemah tidak dapat berbuat apa berdebat (berbicara) dengan sang admak akmitan apigajjih. ${ }^{18}$ setiap bulan Cetra.$^{19}$, itulah sebabnya

6. menjadikan tidak teraturnya karāman, hancur tidak terlindungi, .......

12. Prasasti Hyang Putih (Goris, no. 803) bertahun Saka 1246, dikeluarkan oleh raja Bhațāra Guru II.

Ib. 3. ....., i pingsornya ājñā pāduka sri mahāraja hajarěn sira kabeh ri gatidopaya nikanang $\mathbf{k a}$

4. raman ing hyang putih sapan̂̀jing thäni, . . . ${ }^{20}$

Terjemahannya lebih kurang sebagai berikut:

Ib. 3. . . . ., adapun isi yang termaktub di dalam perintah Paduka Sri Maharaja yang harus dititahkan kepada beliau semuanya, yaitu mengenai kesusahan (keragu-raguan dalam segala. upaya)

4. karaman di Hyang Putih dengan seluruh penduduknya (wilayahnya).....

13. Prasasti Campaga C (Goris, no. 804) bertahun Saka 1246 dikeluarkan oleh raja Bațhāra Guru II.

Ib. 5. ......, ri gatinikanang karaman ing cāmpaga, ingu

6. sikusik deni karaman ing tumpuhyang, wkasan rinampas tinunon pomahanya, hĕnti tke hingonhingonya kabaih tinawan deni ka

IIa. 1. räman ing tumpu hyang, lunga ta ya alěslěsan maring desa salen, karungu pwa ya denira päduka bhatara sri mahăguru, i karāman ing cāmpaga sah ri pa

2. nagaranya ingawasakên ta ya ri desanya tuhu ru sakkäsamun tan hana katmu wwangnya salah tunggal . . . (Callenfels, 1926: 50) 
Terjemahannya lebih kurang seperti di bawah ini:

Ib. 5. . . ..., mengenai kesusahan karäman di Campaga,

6. diganggu oleh karāman Tumpuhyang kemudian dirampas dan dibakar rumahnya sampai habis semua binatang piaraanya ditawan oleh

IIa. 1. karāman Tumpuhyang, pergilah mereka lari ketakutan ke desa lain. Didengarlah mereka oleh Paduka Bhațara Sri Mahāguru bahwa karäman di Campaga mengungsi dari

2. desanya. Dilihatlah desanya betul-betul rusak dan kosong tidak dijumpai salah seorangpun penduduknya (orangnya), ...

\section{URAIAN SINGKAT.}

Memperhatikan data pada beberapa prasasti di atas dapat diketahui bahwa masing-masing prasasti mempunyai sambandha yang berbedabeda. Berdasarkan perbedaan sambandha prasasti tersebut maka jelas dapat diketahui adanya latar belakang perbedaan masalah yang dihadapi oleh masing-masing karäman. Masalah yang dihadapi oleh karäman atau penduduk itulah kemudian disampaikan kepada raja. Dalam hal ini dapat pula kita ketahui bahwa segala permasalahan yang dihadapi oleh karäman atau penduduk semuanya diketahui oleh raja. Melalui persidangan leng. kap di istana (ri pakira-kirān i jro makabehan) masalah itu diselesaikan sebagaimana mestinya dan akhirnya raja membuat keputusan yang kemudian dituangkan dalam bentuk prasasti. Pada umumnya masalah yang dihadapi oleh karăman atau penduduk dicantumkan pada prasasti yang dimuat pada bagian sambandha.

Menurut keterangan M.M. Sukarto K. Atmojo bahwa bagian sambandha merupakan bagian yang penting karena dengan demikian akan dapat mengetahui alasan atau sebab apakah raja mengeluarkan prasasti. Tetapi penyebutan istilah sambandha umumnya hanya terbatas pada prasasti yang cukup panjang sedangkan prasasti pendek lainnya tidak menerangkan secara jelas, meskipun penulisan sebuah prasasti pasti berkaitan dengan alasan-alasan tertentu. Bahkan prasasti yang panjang kerapkali tidak menyebut sambandha (Sukarto K. Atmojo, 1981: 14). Apa yang dikemukakan di atas ini memang demikian adanya, karena dengan sejumlah contoh yang kami kemukakan di atas ada yang menyebut sambandha dengan jelas dan ada pula yang tidak menyebut sambandha secara jelas latar belakang masalahnya.

Berdasarkan contoh tersebut di muka sambandha prasasti itu menyebutkan beraneka ragam permasalahan dari masalah pajak (drwyahaji), bwatthaji, dan buñcang haji, ingin menjadi desa berdiri sendiri, tanah pertanian (jatāka, sỉma dan membuat sawah baru) perampokan/perampasan, perbuatan curang para petugas kerajaan (sang admak akmitan apigåjih, cakșu paracakșu), ingin mengganti ripta yang sudah rusak dan sebagainya kesemuanya itu merupakan latar belakang masalah terbitnya prasasti. Permasalahan itu diketahui oleh raja serta perangkat kerajaan yaitu para 
tanda rakryan (para pendeta agama Siwa dan agama Budha, senāpati, semangat/samgět dan sebagainya).

Mengenai masalah pajak (drwyahaji), bun̂cang haji dan bwatthaji, sebagai latar belakang masalah disebutkan pada prasasti Serai A II (Goris, no. 302), Sembiran A III (Goris, no. 351), dan Sawan (Goris, no. 353).

Pada prasasti Serai A II disebutkan orang-orang yang sudah melakukan bwatthaji di Buru juga dikenakan drwyahaji setiap tahun sebesar 9 mäsu tetapi mereka tidak dapat membayar pajak rot itu. Sedangkan pada prasasti Sembiran A III disebutkan sebagai pangkal masalah berkurangnya jumlah penduduk yang pada mulanya berjumlah 300 keluarga bersisa hanya 50 keluarga karena ada yang mati, ditawan musuh serta ada yang mengungsi ke tempat lain, sehingga penduduk yang tinggal sedikit itu tidak dapat membayar drabyahaji (drwyahaji) sampai dengan buñcang haji, hal itu menyebabkan mereka sakit/susah hati. Masalah yang serupa dengan yang disebutkan pada prasasti Sembiran A III juga disebut pada prasasti Sawan, bahwa penduduk yang pada mulanya berjumlah 50 keluarga tinggal bersisa 10 keluarga sehingga mereka merasa berat untuk membayar dṛwyahaji serta melakukan buñcang haji besar maupun kecil termasuk pinta palaku pamli dan pikul-pikulan.

Gambaran lain yang ditemukan pada prasasti Sembiran A III adanya gangguan keamanan terhadap penduduk berupa tindak kekerasan seperti pembunuhan, penawanan dan juga menyebabkan terjadinya pengungsian. Barangkali berkurangnya jumlah penduduk seperti yang disebut pada prasasti Sawan diakibatkan oleh tindak kekerasan juga. Sayang sekali kami tidak dapat mengetahui siapakah yang dikatakan musuh dalam prasasti Sembiran A III itu. Berlainan halnya keterangan yang kami peroleh pada prasasti Campaga C (Goris, no. 804) bahwa kesusahan karāman Campaga karena diganggu oleh karāman Tumpuhyang disertai dengan pembakaran rumah penduduk, perampasan hak milik dan penawanan terhadap binatang piaraan serta penduduk semua mengungsi ke desa lain. Dalam masalah ini raja Bhațāra Śri Mahāguru (Bhatāra Guru II) langsung mengadakan pemeriksaan terhadap karāman Campaga dan menjumpai karāman Campaga betul-betul kosong tidak ditemukan seorang pendudukpun. Kemudian raja memerintahkan supaya pulang ke rumahnya masing-masing. Sebagai tindak lanjut akibat dari gangguan karăman Tumpuhyang itu karāman Campaga dipisahkan dengan karäman Tumpuhyang menjadi desa berdiri sendiri.

Bila dalam prasasti Campaga $\mathrm{C}$ disebutkan raja memisahkan karāman Campaga dengan karāman Tumpuhyang sebagai tindak kekerasan dari karäman Tumpuhyang, pada prasasti Bwahan A (Goris, no. 303) tidak disebutkan latar belakangnya mengapa karāman tepi danau Bwahan ingin memisahkan diri dari karäman tepi danau Kdisan. Dalam usahanya untuk memisahkan diri untuk mereka (karāman tepi danau Bwahan) dengan cara 
baik-baik (musyawarah) memohon kehadapan raja supaya diijinkan menjadi desa berdiri sendiri serta memohon prasasti. Permohonan prasasti ini dapat dimaklumi yaitu sebagai bukti pengesahan (penetapan) bahwa karäman tepi danau Bwahan telah berdiri sendiri tidak terikat lagi dengan karāman tepi danau Kdisan. Walaupun pada prasasti tidak disebutkan alasan karāman tepi danau Bwahan memohon kepada raja untuk memisahkan diri dengan karäman tepi danau Kdisan dapat dipastikan ada sebabsebabnya. Kiranya sebab-sebab itu dipandang tidak perlu ditonjolkan dalam prasasti yang mungkin akan dapat menimbulkan suatu masalah, mengingat antara kedua karaman itu letaknya berdampingan. ${ }^{21}$

Prasasti yang sambandha-nya yang mempunyai latar belakang masalah yang ada sangkut-pautnya dengan tanah pertanian ialah prasasti. Batuan (Goris, no. 352), Pandak Bandung (Goris, no. 436), Klungkung A (Goris, no. 439) dan Tejakula (Goris, no. 571). Prasasti Batuan menyebutkan bahwa karàman Baturan merasakan beratnya buĭcang haji menjaga kebun baginda raja yang lumah (dicandikan) di Er Wka (Udayana) dan di Er Paku (?). Dari prasasti itu dapat pula diketahui bahwa kedua tempat lumah (candi) bagi raja yang sudah mencapai alam dewa (dewata) mempunyai tanah laba pura (jatăka) berupa kebun yang hasilnya dipergunakan untuk memelihara bangunan itu. Berbicara masalah tanah kebun adalah tanah pertanian yang tidak memerlukan pengairan. Hanya saja kita tidak mengetahui berupa perkebunan apa milik raja yang lumah di Er Wka dan di Er Paku itu. Sedangkan pada prasasti Pandak Bandung disebutkan bahwa raja (Anak Wungsu) mempersembahkan sima Marajang diperuntukkan bagi (dijadikan) milik sanghyang dharma di Antakuñjarapāda. Tanah (\$ima Marajang) itu pada mulanya dijual oleh keturunan raja yang lampau (almarhum) yang dicandikan di Senämukha. Siapakah nama raja yang dicandikan di Senãmukha tidak kami ketahui dan di mana letak Senämukha masih memerlukan penelitian lebih lanjut. Seperti disebut dalam prasasti bahwa keturunan baginda yang dicandikan di Senàmukha bernama Dyah̆ Jasa, Dyah Manali dan Dyah Citta. Lebih lanjut disebutkan bahwa tanah sima itu terdiri atas hutan, sawah dan kebun. Mengapa hutan dimasukkan sebagai sima hal ini dapat dimaklumi karena hutan memberikan persediaan kayu yang diperlukan untuk bahan bangunan suci. Dengan disebutnya tanah sawah dapat kita ketahui bahwa sudah dikenal adanya bangunan pengairan. Pada prasasti Klungkung A disebutkan adanya keinginan membuat sawah yaitu sawah kadandan yang terletak di kaswakan Rawas. Sehubungan dengan pembuatan sawah itu setiap orang supaya membayar Iăga pariduh sebesar 5 ma seperti peraturan yang berlaku sejak dahulu. Dalam hal pembuatan sawah baru, kiranya terlebih dahulu harus menyampaikan kepada raja tidak boleh dilakukan begitu saja. Mengapa harus disampaikan kepada raja? Hal itu dapat dimaklumi, sawah merupakan tanah pertanian yang lebih penting jika dibandingkan dengan tanah pertanian lainnya. Dalam hal pajak pada umumnya tanah sawah lebih besar dibandingkan tanah kebun. Menurut hemat kami pembuatan sawah baru ha- 
rus memberitahukan terlebih dahulu kepada raja karena ada sangkut pautnya dengan masalah pajak. Pada prasasti Tejakula disebutkan bahwa raja menuniuk karàman Sabhaya untuk mengerjakan tanah jatāka (laba pura) milik bangunan suci Bhatăra Kunjarasana. Raja tidak begitu saja memerintahkan karāman Sabhaya mengerjakan tanah jatäka itu tetapi terlebih dahulu memanggilnya untuk bermusyawarah. Rakyat Sabhaya datang menghadap raja untuk mengadakan tatap muka untuk memusyawarahkan tentang pengerjaan tanah jatăka. Sayang sekali kita tidak mengetahui jenis tanah jatäka apakah berupa tanah sawah, atau kebun.

Prasasti Trunyan A II sambandha-nya menyebutkan hal yang lain jadi berbeda dengan yang telah dibicarakan di muka. Pada prasasti itu disebutkan tentang permohonan kepada raja untuk mengganti ripta (rontal) yang rusak dengan yang baru terbuat dari tembaga. Penggantian ripta yang telah rusak merupakan hal yang penting karena apabila dibiarkan tidak diganti tidak ada yang dipakai sebagai pegangan, sehingga mudah dipermainkan seperti yang disebut pada prasasti Bwahan $C$ yang akan kami: singgung kemudian. Prasasti merupakan benda yang sangat berharga bagi suatu karãman karena merupakan suatu pegangan (agěmmagěm) yang dipakai untuk mengokohkan sarintěn-nya. Boleh dikatakan prasasti merupakan dasar hukum bagi sebuah karäman yang harus :ditaati oleh semua pihak apakah itu rakyat biasa atau pejabat kerajaan baik dari kalangan atas sampai dengan yang terbawah.

Masalah persengketaan penduduk (karāman) dengan pejabat kerajaan dapat diketahui dari sambandha prasasti Bwahan C (Goris, no. 554) dan Campaga A (Goris, no. 631). Pada sambandha prasasti Bwahan $\mathrm{C}$ disebutkan bahwa karäman tepi danau Bwahan menghadap raja karena selalu dipermainkan oleh cakșu paracaksu. Mereka memohon kepada raja supaya diberi pegangan (prasasti) untuk mengokohkan kedudukannya semula yang diwarisi sejak dahulu. Pada sambandha prasasti Campaga $\mathrm{A}$ disebutkan raja mengetahui kesusahan karāman (Campaga) tidak tahu daya upaya, lemah tidak dapat berbuat apa berdebat (berbicara baik dan buruk) dengan sang admak akmitan apigäjih setiap bulan Cetra, menyebabkan karäman tidak teratur (kacau) tidak ada yang melindungi. Oleh karena itu mereka kemudian menghadap raja.

Dari kedua sambandha prasasti di atas ini kita dapat mengetahui adanya perbuatan yang kürang baik dari para pejabat kerajaan sehingga menimbulkan persengketaan dengan penduduk.

Sebagai salah satu contoh prasasti yang sambandha-nya tidak jelas adalah prasasti Hyang Putih (Goris, no. 803). Pada prasasti itu hanya disebutkan bahwa raja mengeluarkan perintah karena kesusahan (tidak tahu daya upaya) karăman Hyang Putih. Tetapi apa yang menyebabkan kesusahan itu tidak ada disebutkan dalam prasasti. Tetapi walaupun demikian dapat diduga pasti ada kaitannya dengan suatu masalah yang menyangkut karàman Hyang Putih. 


\section{PENUTUP}

Dari beberapa contoh yang dipergunakan sebagai sumber penulisan bahwa sambandha prasasti ada yang jelas disebutkan tetapi ada juga yang tidak menyebut sambandha. Berdasarkan uraian kami di atas maka untuk sementara dapat disimpulkan seperti di bawah ini:

1. Raja sebagai tokoh yang mengeluarkan prasasti mengetahui segala permasalahan yang dihadapi oleh penduduk (karāman).

2. Masalah yang dihadapi oleh masing-masing karāman berbeda yang dapat kita ketahui dari masing-masing sambandha prasasti.

3. Prasasti merupakan benda yang sangat berharga bagi satu karāman karena merupakan dasar hukum bagi karäman itu sebab prasasti harus ditaati oleh semua pihak.

\section{CATATAN}

1. Menurut Goris perkataan ini diterjemahkan dengan 'kerja rodi' (Goris, 1954a: 227).

2. Drwya haji berarti 'milik raja'. Yang dimaksud dengan drwya haji ialah segala milik raja yang harus diserahkan oleh penduduk berupa: pajak, iuran, pungutan dan semacamnya untuk raja atau perbendaharaan kerajaan (Ekawana, 1980: 50).

3. Apa sesungguhnya yang dimaksud dengan rot tidak jelas. Bandingkan dengan bahasa Bali panguwot berarti 'uang penebus, uang pembelian' (Goris, 1954a: 298).

4. Nayakan berasal dari kata näyaka (bahasa Sanskerta) berarti 'pemimpin, mandur' (Goris, 1954a: 278). Bila diperhatikan dari konteks kalimat prasasti adalah orang yang bertugas untuk mengawasi orangorang yang melakukan bwatthaji.

5. Karäman berasal dari kata rāma berarti 'ketua desa' (Goris, 1954a: 295). Demikian pula de Casparis menterjemahkan dengan 'village authorities' berarti 'ketua desa, pembesar desa' (de Casparis, 1956: 216). Dalam bahasa Bali terdapat perkataan rĕrama (baca: rĕramと) dipergunakan untuk menyebut ayah dan ibu. Kata rāma di samping berarti seperti di atas ini juga mempunyai pengertian untuk menunjukkan orang yang dihormati di desa karena kedudukannya sebagai pemuka masyarakat,

Karāman mempunyai pengertian 'tempat para rāma' oleh karena itu dapat berarti 'desa dengan anggotanya para rama' (Sukarto K. Atmodjo, 1970: 220-221; Sukarto K. Atmodjo, 1974: 11).

6. Buñ̂cang haji oleh Goris diterjemahkan dengan 'kerja rodi' (Goris, 1954a: 229).

7. Pinta palaku pamli, mungkin semacam iuran yang harus diserahkan oleh penduduk.

8. Sima seharusnya ditulis sima (bahasa Sanskerta) berarti 'batas' (Goris, 1954a: 308). Sumber yang lain memberikan keterangan bahwa 
sïma (daerah perdikan) yaitu tanah bebas dari pajak. Berdasarkan penelitian dari 120 prasasti yang berisi penetapan síma, paling banyak menyebutkan penetapan sima untuk bangunan suci (Mardiwarsito, 1981: 530; Boechari, 1977: 94-95). Sima Marajang yang disebut dalam prasasti Pandak Bandung itu jelas sekali diperuntukkan bagi bangunan suci Antakuñjarapada. Di Bali dewasa ini masih dikenal laba pura yaitu tanah (sawah atau kebun) milik pura di mana hasilnya dipergunakan untuk memelihara atau menyelenggarakan upacara pura tersebut.

9. Punpunan dapat berarti 'para bawahan, kepunyaan, milik, segala harta benda (pusaka)' (Mardiwarsito, 1981: 445). Menurut penelitian Pak Boechari dalam berbagai prasasti terdapat istilah punpunan dan anda untuk menyebut sima. Berdasarkan prasasti Tuhaharu yang berangka tahun 1245 Saka atau 1323 M (O.J.O. LXXXIII) disimpulkan bahwa punpunan ialah sima yang letaknya dekat dengan bangunan sucinya, sedangkan ansa ialah sima letaknya jauh dari bangunan sucinya (Boechari, 1977: 95).

10. Sanghyang dharmma bila diuraikan secara kata demi kata ialah: sang adalah partikel penunjuk orang biasa maupun hormat; hyang berarti 'dewa atau dewata'; sanghyang juga berarti 'dewa atau menunjuk sesuatu yang dianggap suci, mulia', sanghyang dharmma berarti 'pemakaman suci' (Mardiwarsito, 1981: 229 dan 505). Boleh jadi sanghyang dharmma sama padharman yang ada di Bali sekarang. Siapakah yang di-dharma-kan di Antakunjarapāda tidak kami ketahui.

11. Samgat ser camalagi, bila diuraikan satu persatu ialah: samgat merupakan akronim dari sang pamgat; pamgat terbentuk dari kata pgat artinya 'putus'. Di dalam prasasti Jawa Kuna sæmgat juga ditulis samgét (de Casparis, 1956: 220). Sang pamgat artinya 'sang pemutus'; ser artinya 'melalui kepala' camalagi berarti 'asam' (Goris, 1954a: 307 dan 231). Memperhatikan konteks kalimat prasasti menunjukkan suatu jabatan kerajaan, tetapi apa sesungguhnya tugas dari jabatan itu tidak jelas bagi kami.

12. Perkataan kadandan terbentuk dari danda (bahasa Sanskerta) berarti '(peng)gada, denda, hukuman': kadandan artinya 'dihukum, didenda 'digada' (Mardiwarsito, 1981: 166). Dalam bahasa Bali terdapat perkataan dandan artinya 'menuntun'. Sawah kadandan mungkin sawah yang beberapa bagian dari hasilnya harus diserahkan untuk perbendaharaan kerajaan, mengingat pada bagian bawah prasasti disebut seorang pejabat bernama sang admak danda.

13. Kaswakan terbentuk dari kata swak yang sekarang menjadi subak. Seperti kita ketahui sekarang di Bali subak merupakan pemerintahan air yang berwilayah tertentu (rata-rata $80 \mathrm{ha}$ ) berbataskan alam yang jelas seperti: desa, bukit, sungai, jalan dan lain-lainnya memiliki jaringan irigasi yang lengkap (Jelantik Sushila, 1979: 6). Mungkin yang dimaksudkan dengan kaswakan adalah wilayah yang mencakup satu persubakan. 
14. Làga pariduh yaitu lāga berarti 'perlombaan, uang taruhan' (Goris, 1954a: 265); pariduh terbentuk dari kata riduh mungkin sama dengan ridu artinya 'kacau' (Mardiwarsito, 1981: 475). Apakah tidak mungkin låga pariduh merupakan semacam uang iuran yang dipergunakan untuk biaya menjaga keamanan?

15. Caksu paracaksu mungkin semacam jabatan yang bertugas dalam bidang pengawasan. Caksu artinya 'mata'.

16. Jatāka, oleh Ginarsa diterjemahkan dengan 'wilayah tanah suci (laba pura) (Ginarsa, 1974: 29). Goris juga menjelaskan bahwa jataka hampir sama dengan laba pura (Goris, 1957: 22).

17. Perkataan bhațāra (bahasa Sanskerta) mempunyai pengertian yang luas, misalnya berarti 'ketuhanan, hal kedewaan, dewa, gelar dewa termulia, raja, pembesar (Mardiwarsito, 1981: 125). Perkataan bhațāra selain berarti 'raja' (masih hidup) juga untuk menyebutkan raja yang telah meninggal, misalnya Bhațära Banu Wka adalah untuk menyebut Udayana (Goris, 1957: 20).

18. Admak akmitan apigajjih merupakan jabatan kerajaan yang bertugas mengambil dan menjaga hak milik raja barangkali menerima upah (gaji) dari raja.

19. Cetra (sekarang di Bali disebut sasih kěsanga) jatuh pada hari-hari bulan Maret-April. Sasih késanga merupakan bulan terakhir dalam tahun Saka dengan penutup hari tilěm (bulan mati). Tilěm pada sasih kesanga disebut tilem kesanga, pada waktu itu umat Hindu melakukan upacara bhuta yadnya (korban untuk bhuta). Ke esokan harinya jatuh pada hari pertama bagian bulan terang (penanggal pisan, bahasa Bali) adalah Nyepi ialah tahun baru Saka (Guweng, 1973: 20; Dinas Agama Hindu dan Budha, 1970: 48).

20. Teks prasasti ini sekarang disimpan pada Perpustakaan Fakultas Sastra Universitas Udayana.

21. Desa Bwahan terletak di sebelah barat Kdisan berlokasi di tepi danau Batur (Kecamatan Kintamani, Kabupaten Bangli). Desa-desa yang terletak di tepi danau Batur itu sekarang disebut desa bintang danu, ini mungkin merupakan perubahan dari wingkang ranu. Desa-desa lain yang termasuk desa bintang danu adalah: Songan, Trunyan dan Abang. 


\section{KEPUSTAKAAN}

Boechari

1977 "Candi dan Lingkungannya", dalam Majalah Ilmu-Ilmu Sastra Indonesia, Jilid VII, No. 2, Juli, Bhratara, halaman 91-114

1977 ',Epigrafi dan Sejarah Indonesia', dalam Majalah Arkeologi, Th. I., No. 2. Nopember, halaman 1-40.

Callenfels, Dr. P.V. van Stein.

1926 'Epigraphia Balica I', dalam Verhandelingen van het Koninklijk Bataviaasch Genootschap van Kunsten en Wetenschappen, LXVI, 3, G. Kolf \& Co.

Casparis, J.G. de.

1956 "'Selected Inscriptions from the 7th to the 9th century AD.', Prasasti Indonesia II, Masa Baru, Bandung.

Dinas Agama Hindu dan Budha Kabupaten Badung.:

1970 Hari Raya/Rerahinan Bagi Umat Hindu, Denpasar.

Ekawana, I Gusti Putu.

1980 Jaman Pemerintahan Raja Śri Bhațāra Mahaguru Dharmmotunggā Warmmadewā di Bali, (Skripsi), Denpasar.

Ginarsa, Ketut

1974 Prasasti Baru Raja Ragajaya, Lembaga Bahasa Nasional Cabang I, Singaraja.

Goris, Dr. R.

1948 Sejarah Bali Kuna, Singaraja.

1954 Prasasti Bali I, Masa Baru, Bandung.

1954a Prasasti Bali II, Masa Baru Bandung.

1957 "Dinasti Warmadewa di Pulau Bali', dalam Bahasa dan Budaya, Majalah Ilmiah Populer No. 3. Lembaga Bahasa dan Budaya Fakultas Sastra Universitas Indonesia, Jakarta.

Guweng, Ketut.

1973 ''Wariga"' dalam Warta Hindu Dharma No. 65, halaman 17-20.

Jelantik Sushila.

1979 Masalah Pembinaan Subak, Dinas Pekerjaan Umum Daerah Tingkat I Bali, Denpasar.

Machi Suhadi.

1978 "References To Tax Systems in Old Javanese Inscriptions" dalam Aspek-aspek Arkeologi Indonesia, No. 6, Pusat Penelitian Purbakala dan Peninggalan Nasional, Departemen P \& K, Jakarta. 
Mardiwarsito, L.

1981 Kamus Jawa Kuna - Indonesia, Nusa Indah, Ende. Purwita, Ida Bagus Pt.

1981 "Subak Dalam Lintasan Sejarah Bali" dalam Widya Dharma, Majalah Dwibulanan, No. 2 Tahun I/Oktober 1981, Denpasar, halaman 29 - 33.

Riboet Darmosoetopo.

1980 'Sedikit Uraian Tentang Pergantian Tahta'' (Kerajaan Indonesia kuna dari abad 4-11 M), dalam Seri Penerbitan Balai Arkeologi Yogyakarta, Th. I No. 1 Maret, Yogyakarta, halaman 52 - 57.

Sukarto K. Atmodjo, M.M.

1970 'Preliminary Report On the Copper-Plate Inscription Of Asah Duren"' dalam Bijdragen Tot De Taal En Volkenkunde, Deel 126, 2e Aflevering, 'S-Gravenhage-Martinus Nijhoff, halaman 215-227.

1974 The Charter Of Kapal, dibawakan dalam Sixth International Conference On Asian History International Association Of Historians Of Asia, Yogyakarta.

1981 Metode Penelitian Dan Analisa Sumber-Sumber Epigrafi, dibawakan dalam Rapat Evaluasi Metode Penelitian Arkeologi, Pusat Penelitian Arkeologi Nasional, Yogyakarta. 